\title{
'Study of several involuntary functions of the apparatus of movement, gripping, and voice' by Jean-Marc Gaspard Itard (1825)
}

Introduction and translation by

SARA NEWMAN*

Kent State University

Itard's 1825 paper, written while he was Chief Physician at the National Institute for Deaf-Mutes in Paris, demonstrates his empiricist approach to medicine. That is, Itard founded his medical practice on sense and experience rather than on surgery and medication. If all knowledge came through the senses, Itard reasoned, those lacking knowledge or social abilities could be improved by appropriate sensory stimulation. This concern with senses and society, along with his different approaches to men and women, his references to contemporary cures and his comparisons between humans and animals, document early nineteenth-century medical and psychological attitudes and treatments. Itard's paper also contains what was later recognized as the first clinical observation of Gilles de la Tourette Syndrome (TS).

Keywords: coprolalia; feral child; F. M. G. Itard; movement disorder; National Institute for Deaf-Mutes, Paris; tic; Tourette Syndrome

\section{Introduction and biography}

Jean-Marc Gaspard Itard (1775-1838) is perhaps best known as the physician who attempted to civilize 'the wild child of Aveyron'. Those efforts, interesting in and of themselves, belong to and typify a more productive life, one dedicated to the improvement of the mental and physical health of his fellow humans, particularly those less well-endowed intellectually or physically. In

\footnotetext{
* Address for correspondence: Department of English, Kent State University, PO Box 5190, Kent, OH 44242-0001, USA. Email: snewman@kent.edu
} 
this, his work also typifies a moment in Western culture when the desire to understand human nature becomes the object of the new scientific method. Itard's 1825 paper, translated here for the first time, not only represents an Enlightenment perspective on medical practices but also contains what was later recognized as the first clinical observation of Gilles de la Tourette Syndrome (TS).

Born on 24 April 1775 in Oraison in the Basses-Alpes, Itard was educated to be a banker, but, by chance, became a physician. To avoid conscription during the French Revolution, he sought work at a military hospital in Toulon and was assigned as an assistant surgeon. With this training and some apparent talent, Itard was awarded a surgical internship in a Parisian hospital in 1796. In 1800, again by chance, he became Chief Physician at the newly founded National Institute for Deaf-Mutes in Paris, a position he held for the rest of his career (Lane, 1976; Malson, 1972).

Early in his tenure at the National Institute (and eager to impress), Itard took on the task of teaching Victor, an apparently feral child, captured in 1798 in a remote part of southern France. We will never know with certainty if the boy was retarded, autistic, or delayed in some other way, nor how he came to live in the woods. More certain, however, is that Victor was aged 11-13 at the time of his capture, that he had been a local scavenger for several years in Aveyron, and that he completely lacked the trappings of any social experiences.

Victor's haunting story has been discussed extensively in word and image, based largely on Itard's two reports (Itard, 1801, 1801/1962, 1807; Lane, 1976; Malson, 1972; Shattuck, 1980/1994; Truffaut, 1970). ${ }^{1}$ It is relevant here because the boy's presence at the Institute allowed the young and ambitious Itard to develop his empirical medical practices. His overall approach, based on observation, training and education rather than on medication or surgery, was the legacy of his teacher, Philippe Pinel, the socalled founder of modern psychiatry (Ball, 1971; Lane, 1976). From Pinel, Itard also learned to recognize the limits of his own knowledge and intelligence, to be sensitive towards the mentally or physically ill, and to be sceptical about all scientific inquiry (Malson, 1972).

In philosophical terms, Itard was influenced by Étienne de Condillac and, to a lesser extent, John Locke. Generally, eighteenth-century thinkers were concerned with understanding how humans know. Condillac and Locke granted priority to the senses in knowledge acquisition rather than to abstract disembodied thought, as Rene Descartes did. Condillac, in particular, argued that humans learn when their senses are appropriately stimulated. Because, he also argued, such stimulation was best gained through varied social interactions, being part of society was a key to being fully human. This perspective allowed that humans could improve their lot in life. But, it also meant that some people were higher than others in the hierarchy of words and deeds, the abilities that made humans unique among all species of 
animal. Emmanuel Kant and Jean Jacques Rousseau took yet a different approach. They believed the existence of social problems proved the opposite: humans became more fallible as they became more civilized. Thus, socialized people had much to learn from individuals in their natural state. Given the different characters of these perspectives, it is not surprising that the anthropological and evolutionary sciences developed at this time, disciplines which addressed the question of human nature from various ends of a spectrum, ranging from the most superior forms of humans at one end to the lowest of animals at the other. According to some classifications, feral man belonged somewhere in between (Lane, 1976).

Against this background, Victor was not only a general curiosity but also a perfect object for scientific examination. A wild child - part human, part animal, unsocialized and mute - might well provide insights into innate thoughts, human speech and the relationship between humans and other animals. Both the title of Itard's first report and its opening statement reflect his immersion in these issues. Thus, An historical account of the discovery and education of A SAVAGE MAN, or of the developments, physical and moral, of THE YOUNG SAVAGE caught in the woods near Aveyron, in the year 1798 begins:

Cast upon this globe without physical strength or innate ideas, incapable in himself of obeying the fundamental laws of his nature which call him to the supreme place in the universe, it is only in the heart of society that man can attain the preeminent position which is his natural destiny. Without the aid of civilization he would be one of the feeblest and least intelligent of animals - a statement which has been many times repeated, it is true, but has never been strictly proven. (Lane, 1976)

Following Condillac and Pinel, Itard founded his medical practice on sense and experience. If all knowledge came through the senses, Itard reasoned, those lacking knowledge or social abilities could be improved by appropriate sensory stimulation. According to prevailing sentiment, the boy would remain little more than an animal; even Pinel deemed Victor incurably retarded (Itard, 1801/1962). For Itard, as indicated above, Victor's savage nature was not necessarily permanent. Having suffered extensive sensory deprivation in the wild, he was developmentally delayed. To rectify the delay, Itard exposed Victor to a five-step series of sensory experiences, gradually stimulating him to reach the developmental level of boys his age. In this way, and with much repetition, Itard attempted to integrate Victor into society (Itard, 1801/1962).

Itard's attitude and approach challenged contemporary thinking on matters of heredity, intelligence and learning. He not only held that an individual's intelligence depended on nature and nurture (Ball, 1971), but his perspective, indebted to Pinel, led to new ways to classify human behaviour. Before 1800, individuals were either normal or insane, and the latter had no hope of 
improving themselves, let alone functioning in society. For Itard and likeminded physicians, some people were mentally retarded. Though limited intellectually, the retarded could at the least be helped (granted, the concept is not without its own serious flaws).

Itard failed to socialize Victor and to resolve any of the dilemmas his existence seemed to pose. The boy did respond at times to the kindness of his caretaker; he uttered noises and cries, and apparently understood some of what others said to him, but he was never able to speak or belong in society. Sadly, Victor remained in the Institute until his death in 1828 - a man, or child, in his 40s. Many wonder if he might have been better off in the wild, to where he always wanted to return (Shattuck, 1980/1994).

If Itard did not improve Victor's life, the experience helped him establish specific practices for teaching other individuals with varying intellect (Kanner, 1967; Malson, 1972). In particular, Itard pioneered sensory, deaf and special educations. He was among those, for example, who participated in debates over the relative value of lip-reading and sign language for the deaf (Lane, 1976; Malson, 1972). Based on Itard's work, Eduard Seguin designed non-verbal intelligence tests. In turn, these ideas influenced Sequin's student, Maria Montessori, whose sensory teaching method is still practised worldwide (Ball, 1971; Itard, 1801/1962; Kanner, 1967). Finally, in his role as chief physician at the Institute, Itard forged new ground in the diagnosis and treatment of ear diseases. He founded otorhynolaryngology, developed the Eustachian tube catheter, or Itard's catheter, and wrote the first modern book on ear diseases (Itard, 1821). His many books and articles also take up dropsy, mutism and stuttering, and he edited various journals: 1816, coeditor of Fournal Universal des Sciences Médicales; 1832, editor of the Revue Médicale; 1832, editor of the Dictionnaire de Médicine ou Répertoire Générale des Sciences Médicales sous le Rapport Théorique et Pratique.

The paper translated here was part of his efforts at the National Institute to improve his patients' health by means of observation and therapeutic interventions. In particular, Itard discusses ten individuals, seven men and three women, who presented with uncontrolled movements of their legs, hands and vocal chords. As he states at the paper's conclusion, his goal was to examine the symptoms, origins and treatment of these spastic convulsions rather than to name a new disease. Ironically, he may have done the latter, since Itard's last observation was later appropriated as the first clinical description of TS. It is important to focus for a minute on this observation. It considers the Marquise de Dampierre, a distinguished member of polite society and a sufferer of coprolalia, or uncontrolled swearing. Given her social prominence, she was (like Victor) a curiosity to the general public and an opportunity for scientists to examine the human condition. Accordingly, the case appears in various nineteenth- (and twentieth-) century medical sources associated with the nascent field of neurology. In fact, after 1825, subsequent references to the Marquise were copied nearly verbatim from 
Itard's paper. None of the physicians observed her clinically, although they may have seen the well-known woman in Paris (Kushner, 1999). For these reasons, it is important to make the complete text available. The disorder, after it appeared in George Gilles de la Tourette's 1885 paper about involuntary movements, acquired his name, no doubt with the support of his mentor, J. M. Charcot of Salpêtrière Hospital in Paris (Goetz, 1987; Yorston and Hindley, 1998).

Read in its entirety and in its historical context, Itard's paper complements his work with Victor. In this case, Itard applies his empiricist method to individuals with normal intellect. Why, Itard asks implicitly, would otherwise normal people (i.e., of normal intelligence, of appropriate education and breeding) move and/or speak in socially inappropriate, inconvenient or dangerous ways against their own better judgement?

According to Itard's evaluation, the convulsions are due to brain lesions. But, this responsibility differs along gender lines. In the men, the lesions are the sole cause of their convulsions, gesturing and feverish pacing. Thus, their brain function has been co-opted but their will remains intact. Although lesions affect the women, too, they are responsible only in part. Their physical and vocal convulsions also depend on stressful circumstances in the women's lives, circumstances involving puberty, marriage and childbirth. As a result, Itard believes the women have some control over their inappropriate movements and statements. To help to develop this control, he espouses various cures including bleeding, leeching, bathing, herbal medications. Itard also refers to moral medicine, an extremely popular nineteenth-century cure which attempted to improve health by means of lifestyle changes involving fresh air, healthy food and exercise (Goldstein, 1987).

Itard's different approaches to men and women, his references to contemporary cures and his comparisons between humans and animals document early nineteenth-century medical and psychological attitudes and treatments. In the end, Itard exhibits the personal sensitivity with which he defended the mentally deficient, as well as a cultural insensitivity which equated weakness of will to animalistic subhuman behaviour, evident especially in women. And again, Itard's sympathy with the afflicted individuals he observes is unusual for the time, and also characterizes their problems within the framework of cure rather than acceptance.

During his career, Itard saw wealthy patients in his private, residential practice and other patients at the Institute. By all accounts, he was hardworking, dedicated, not especially gregarious, and a perfectionist. His many carefully written works pay testimony to the care with which he thought out and practised his craft. According to contemporary reports, he resembled Henri IV (Malson, 1972) and avoided social gatherings, but was generous with both time and money to students, colleagues and worthy causes. Increasingly incapacitated by a painful illness, he grew more insular and taciturn in his final years. He moved to Passy to be more comfortable where, 
never married and with few relations kin and close friends, he enjoyed solitary pastimes such as woodworking and walking in nature, as he had with Victor. He died on 5 July 1838 at his home; he had been a medical success with no formal degree or education (Itard, 1801/1962; Lane, 1976; Shattuck, 1980/94).

\section{Style of the translated text}

In the translation which follows, every effort has been made to preserve the style of the original French rather than to render it in more contemporary English. The original footnotes are retained. All italics are Itard's own. When necessary, I give a clarification in square brackets. In these ways, I hope to remain as close as possible to the original meaning, and to capture the historical context in which the document appeared. Although this means that today's reader must accept Itard's penchant for comas and semicolons, he or she will gain a sense of the concerns and materials with which Itard grappled.

\section{Note}

1. To read Itard's account of Victor in translation, see Itard (1801/1962) and Malson (1972); for background and interpretation, see Harlan (1976) and Shattuck (1980/1994). All these publications provide extensive bibliographies.

\section{References}

Ball, T. (1971) Itard, Seguin, and Kephardt: Sensory Education - A Learning Interpretation (Columbus, OH: Charles E. Merrill Publishing Co.).

Gilles de la Tourette, G. (1885) Étude sur une affection nerveuse caracterisée par l'incoordination motrice accompagnée d'écholalie et de coprolalie (jumping, latah, myriachit). Archives de Neurologie, 9, 19-42, 158-200.

Goetz, C. G. (ed.) (1987) Charcot the Clinician: The Tuesday Lessons (New York: Raven Press).

Goldstein, J. (1987) Console and Classify: The French Psychiatric Profession in the Nineteenth Century (New York: Cambridge University Press).

Itard, J. M. G. (1801) De l'Éducation d'un homme sauvage ou de premiers developments physiques et moraux de jeune sauvage de l'Aveyron (Paris, Gouyon).

Itard, J. M. G. (1801/1962) The Wild Boy of Aveyron, translated by G. Humphrey and M. Humphrey (New York: Appleton-Century-Crofts).

Itard, J. M. G. (1807) Rapport fait à s.e. le Ministre de l'Interieur sur nouvaux developpements et l'état actuel du sauvage de l'Aveyron (Paris: Imprimerie imperiale).

Itard, J. M. G. (1821) Traité sur des maladies d'oreille et de l'audition, 2 vols (Paris: Mequignon Marvis).

Itard, J. M. G. (1825) Mémoire sur quelques fonctions involontaires des appareils de la locomotion, de la préhension et de la voix. Archives Generales de Médecine, 8, 385-407.

Kanner, L. (1967) Medicine in the history of mental retardation. American fournal of Mental Deficiency, 72 (2), 165-70. 
Kushner, H. (1999) A Cursing Brain? The Histories of Tourette Syndrome (Cambridge, MA: Harvard University Press).

Lane, H. (1976) The Wild Boy of Aveyron (Cambridge, MA: Harvard University Press).

Malson, L. (1972) Wolf Children and the Problem of Human Nature (New York: The Monthly Review Press).

Shattuck, R. (1980/1994) The Forbidden Experiment: The Story of the Wild Boy of Aveyron (New York: Farrar Straus Giroux).

Truffaut, F. (1970) The Wild Child/L'Enfant Sauvage [Motion picture] (Les Films du carrosse, Les Productions Artistes associés).

Yorston, G. and Hindley, N. (1998) Study of a nervous disorder characterized by motor incoordination with echolalia and coprolalia. The introduction and case studies of Gilles de la Tourette's 1885 paper. History of Psychiatry, 9, 97-120.

Classic Text No. 67

\section{'Study of several involuntary functions of the apparatus of movement, gripping, and voice'}

\section{by Jean-Marc Gaspard Itard (1825)*}

When the muscles which animate our lives are no longer controlled by the will, because a morbid stimulus provokes contractions and produces convulsions, these violent and repetitive movements are especially disorganized, tumultuous, and nonfunctional. Yet, there are numerous anomalies of the nervous system which exemplify the contrary. Thus, it is not impossible that in the midst of the free exercise of its other functions, the brain would suddenly be deprived of its control over some of the muscular apparatuses, apparatuses entirely subject to the brain; those functions which serve in their place, such as we see in ordinary convulsions, alternate rapidly between contractions and relaxations; they begin to perform more or less regular movements which replace some of the functions they are supposed to execute under the exclusive influence of the will. Such conversion of our voluntary actions into automatic movements cannot be a very rare phenomenon; examples include stretching, yawning, laughing when we are

* Itard, J. M. G. (1825) Mémoire sur quelques fonctions involontaires des appareils de la locomotion, de la préhension et de la voix. Archives Generales de Médecine, 8, 385-407. 